\title{
History of Exclusive Breastfeeding and Complementary Feeding as a Risk Factor of Stunting in Children Age 36-59 Months in Coastal Areas
}

\author{
Nancy Swanida Henriette Malonda* \\ Finny Warouw Paul Arthur Tennov Kawatu Yulianty Sanggelorang \\ Faculty of Public Health, Sam Ratulangi University
}

\begin{abstract}
Objective: To determine the relationship between the history of exclusive breastfeeding, birth weight, maternal knowledge, maternal education, maternal age during pregnancy, maternal nutritional status before pregnancy, and Complementary Feeding with the incidence of stunting in children aged 36 - 59 months. Method: This research was a descriptive analytic study with cross sectional approach, which was carried out for 6 months, from April to October 2019. The sample population was children aged 36-59 months, who lived with their mothers in the coastal areas of the Sitaro Regency. Sampling was done by purposive sampling to get 204 samples. Data collection using questionnaires by interview, secondary data in the Maternal and Child Health (MCH) book, and anthropometric measurements namely height by age, for Stunting variables, and analysis of Body Mass Index for maternal Nutrition status. Data analysis using chi-square test and Fisher exact. Results: Univariate analysis results obtained by Stunting in 52 children or $25.5 \%$. The description of risk factors analyzed were, history of exclusive breastfeeding $67.2 \%$, low birth weight $6.9 \%$, maternal knowledge level less $2.5 \%$, maternal education level low 25\%, maternal age during pregnancy less than 20 years there were $45.1 \%$, status malnourished mother's nutrition before pregnancy which is not normal 30.4\%; and Provision of Complementary Feeding which is not appropriate $22.5 \%$. Bivariate test results obtained a history of exclusive breastfeeding $(95 \%$ $\mathrm{CI} ; \mathrm{p}=0.000)$ and Complementary Feeding $(95 \% \mathrm{CI} ; \mathrm{p}=0.016)$ have a significant relationship with the incidence of Stunting. The results of the analysis on Birth Weight, Maternal Knowledge, Maternal Education, the age of the mother during pregnancy, and the nutritional status of the mother before becoming pregnant, obtained no significant relationship with Stunting $(\mathrm{p}>0.05)$. Conclusion: History of exclusive breastfeeding and Complementary Feeding as a risk Factor of Stunting.
\end{abstract}

Keywords: Exclusive breastfeeding, Complementary Feeding, Stunting

DOI: $10.7176 / \mathrm{JHMN} / 70-07$

Publication date: January $31^{\text {st }} 2020$

\section{Introduction}

Stunting is a condition of failure to thrive in children under five (under 5 years old) due to chronic malnutrition so that the child is too short for his age. Malnutrition occurs since the baby is in the womb and in the early period after the baby is born however, the condition of stunting only appears after the baby is 2 years old. Riskesdas 2013 report, the prevalence of stunting in children under five in Indonesia is 37, 3\%. This figure shows no decrease compared to 2010 (35.6\%) and 2007 (36.8\%). Based on data found in 2017 in the Nutrition Status Monitoring Pocket Book in North Sulawesi, the prevalence of nutritional status of children under five years old from 0-59 months according to HAZ found very short toddlers at $14.1 \%$ and short toddlers at $17.3 \%$. The prevalence of Stunting in Sitaro Islands Regency is $38.45 \%$. Stunting is caused by multi-dimensional factors and not only due to malnutrition factors experienced by pregnant women and children under five. The most decisive intervention to be able to reduce the stunting prevalence is therefore it needs to be done in the First 1000 Days of Life of a toddler. Some factors that cause stunting are the low access to food in terms of quantity and quality of nutrition, behavior, environment (social, economic, cultural, political), and health services. Poor parenting practices, including lack of maternal knowledge about health and nutrition before and during pregnancy, as well as after delivery. Some facts and information show that $60 \%$ of children aged $0-6$ months do not get breast milk exclusively, and 2 out of 3 children aged 0-24 months do not receive complementary food breast milk (complementary feeding). Complementary feeding was given / started to be introduced when toddlers aged over 6 months. Besides functioning to introduce new types of food to infants, complementary feeding can also meet the nutritional needs of the baby's body which can no longer be supported by breast milk, as well as forming endurance and the development of the child's immunological system for food and drinks. Genetics is the health determinant factor that has the smallest influence on the incidence of stunting (TNP2K, 2017).

Stunted toddlers will have a level of intelligence that is not optimal, making children more vulnerable to disease and in the future can be at risk of decreasing levels of productivity. In the end stunting will broadly hamper economic growth, increase poverty and widen inequality. In addition, stunting can also contribute to widening inequality, thereby reducing $10 \%$ of total lifetime income and also causing intergenerational poverty 
(TNP2K, 2017).

Coastal community life is a concern in the field of public health because in the coastal area is an area that directly borders the seafront, where the lives of coastal communities are faced directly with hard ecosystems and highly dependent on marine products because the community conducts economic activities related to ocean resources with income which is so small to support one's own family and the results are only sufficient to meet the needs in a very short period of time. Because of the very low income and low parental education, it has an effect on the mother's parenting, in this case the practice of feeding and caring for children who are not good and in the coastal areas many of the children's nutritional needs are not met and are prone to disease (Hajar et al. 2018).

This study aims to determine the risk factors for stunting in children aged 36 - 59 months in the Coastal District of Sitaro Islands Regency.

\section{Methods}

This research is a descriptive analytic study with cross sectional approach, conducted for 6 months, namely April- October 2019. The sample population is children aged 36-59 months, who live with their mothers in the coastal areas of the Sitaro Regency. Sampling was done by purposive sampling to get 204 samples. Data collection using questionnaires by interview, secondary data in the Maternal Child Health $(\mathrm{MCH})$ book, and anthropometric measurements namely height by age, for stunting variables, and analysis of Body Mass Index for maternal Nutrition status. Data analysis used chi-square test and Fisher exact test.

\section{Ethical Considerations}

Ethical approval was given by the Sam Ratulangi University Faculty of Public Health Ethics Commission. All participants involved in this study were told about the nature of the study, the purpose of the study, and the confidentiality of the data. Participation of subjects was entirely voluntary, and oral consent was obtained from each mother before their children were recruited into the study. All subjects were free of physical disabilities and did not suffer from any illness at the time of data collection. To avoid selection bias, subjects were examined for any nutritional deficiencies and related disorders.

In cases where the respondent is illiterate, we ask an educated person from the community to read the consent form and explain it to the head of the family. Then we got the respondent's thumbprint. In those cases, people who read the consent form also sign as witnesses.

Interviews are given after approval. This protocol is reviewed by a small group of experts who have experience working in centers for nutrition recovery and education and amended based on their recommendations.

\section{Results}

\section{Characteristics of respondent}

This research was conducted on people who live in coastal areas and islands in the work areas of the Ulu Siau, Talawid, Sawang, Ondong, and Tagulandang Public Health Center. The average condition of the people in the Sitaro district, especially those living on the coast, mostly work as fishermen and housewives with low family income.

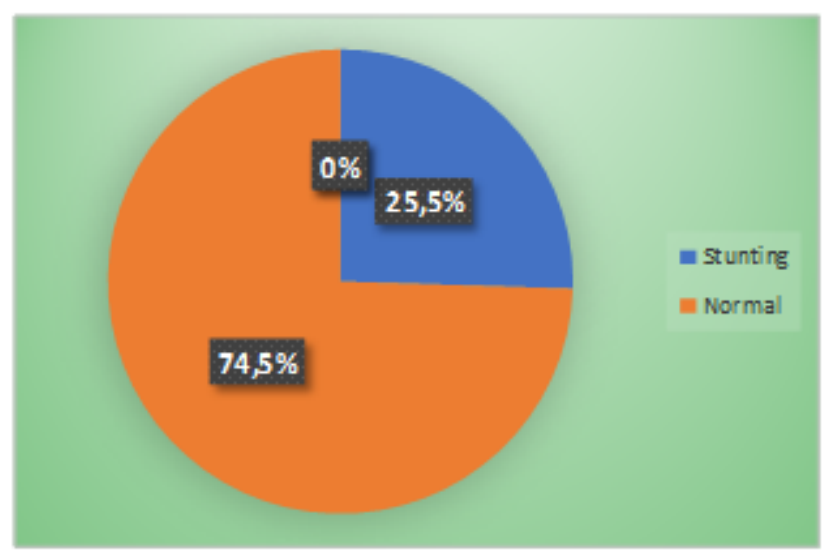

Figure 1. Stunting's Prevalance

Stunting is a condition where a person's height turns out to be shorter than that of another person's height in general (his age). This was found in a study conducted on 204 children aged 36-59 months in the coastal area of the Sitaro archipelago. The results of the univariate analysis were obtained, that there were $25.5 \%$ or 52 children who experienced stunting. 
Table 1. Univariate Analysis

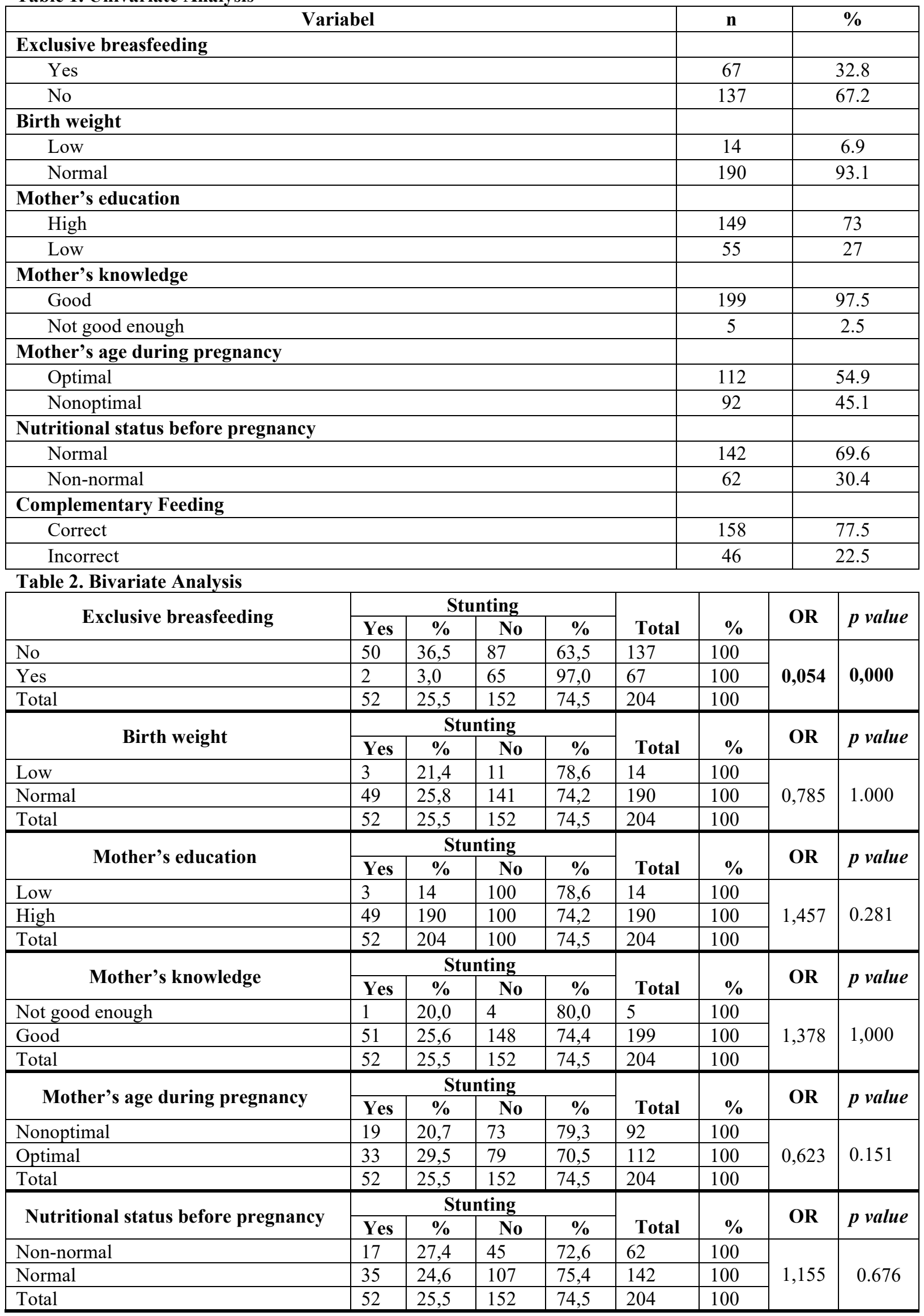




\begin{tabular}{|c|c|c|c|c|c|c|c|c|}
\hline \multirow[t]{2}{*}{ Complementary Feeding } & \multicolumn{4}{|c|}{ Stunting } & \multirow[b]{2}{*}{ Total } & \multirow[b]{2}{*}{$\%$} & \multirow{2}{*}{ OR } & \multirow{2}{*}{ p value } \\
\hline & Yes & $\%$ & No & $\%$ & & & & \\
\hline Incorrect & 18 & 39,1 & 28 & 60,9 & 46 & 60.9 & \multirow{3}{*}{2,345} & \multirow{3}{*}{0.016} \\
\hline Correct & 34 & 21,5 & 124 & 78,5 & 158 & 78.5 & & \\
\hline Total & 52 & 25.5 & 152 & 74.5 & 204 & 74.5 & & \\
\hline
\end{tabular}

Relationship between history of exclusive breastfeeding with stunting

The results showed that $67.2 \%$ or 137 children were not given exclusive breastfeeding, and found $36.5 \%$ or 50 children who experienced stunting. Chi-square statistical test results obtained p value 0.000 shows that there is a significant relationship between the history of exclusive breastfeeding with the incidence of stunting. Breast Milk is a factor that affects nutritional status. Mothers who have a good nutritional state and provide exclusive breastfeeding to children will be able to provide adequate nutrition for infants to grow at a rate that is consistent with the child's growth (Sharlin and Edelstein, 2015). The World Health Organization recommends giving only breast milk to babies from the time the baby is born until the baby is 6 months old (exclusive breastfeeding), and continues to provide breastfeeding until the child is 24 months old. Government Regulation Number 33 Year 2012, explains that mothers who give birth to their babies are required to give exclusive breastfeeding. The exclusive breastfeeding in question is breast milk that is given from the baby is born until the age of 6 months, and is not allowed to have additional and / or replace with other food or drinks. In line with research conducted by Jiang et al. (2015) in the China which showed a relationship between a history of exclusive breastfeeding. In contrast to research conducted by Sari, et al (2017) in the Banjarmasin Public Health Center Work Area, there was no relationship between exclusive breastfeeding and the incidence of stunting.

\section{The relationship between giving complementary feeding with stunting}

chi-square statistical test results showed $p$ value 0.016 means that there is a significant relationship between the provision of complementary feeding with stunting. based on the research conducted, there were 46 children (22.5\%) who were not appropriate or inappropriate in giving complementary feeding. asi complementary food is not only related to food availability, but needs to be considered the frequency, quantity, texture, type, active, and cleanliness requirements. giving complementary feeding aims to meet the needs of infants who will not be sufficiently fulfilled asi. at this time, children are vulnerable to malnutrition, so they need energy and nutrition for physical growth and development. still found in this study, 18 children (39.1\%) were incorrect in giving complementary feeding and stunted. in line with research conducted by Udoh and Amodu (2018), there is a relationship between complementary feeding and the incidence of stunting, children that didn't given adequate complementary feeding more likely to become stunting then they whom given adequate complementary feeding.

\section{The relationship between $\mathrm{LBW}$ and stunting}

Fisher exact statistical test results obtained $\mathrm{p}$ value 1,000 showed that there was no significant relationship between birth weight and the incidence of stunting. In line with research conducted by Rahmadi (2016) showed that there was no relationship between birth weight with the incidence of stunting based on the chi- square obtained p-value 0,966 . Stunting is a nutritional status based on body length index according to age (PB / U) so that body weight is not directly related to the stunting index. Birth weight is a characteristic of infants that is inseparable from the length of the birth body so that birth weight can affect the growth of a child's height. This research is in contrast with research conducted by Kusumawati, et al (2019) on 290 under five children in Banten Province. This study shows that low birth weight is the most dominant factor of stunting, children born with birth weight $<2500$ have a 3.12 times higher chance of experiencing stunting.

\section{The relationship between mother's education and stunting}

Chi-square statistical test results showed $\mathrm{p}$ value 0.281 meaning that there was no meaningful relationship between mother's education level and the incidence of stunting. Based on research conducted by Cholifatun, et al (2015) regarding the level of education with the incidence of stunting shows there is no relationship between maternal education with the incidence of stunting with the results of the chi-square statistical test p-value 0.605 . The level of education of the mother is not related to the incidence of stunting because there are other factors that can affect the nutritional status of a person, including the nutritional status of the mother during pregnancy where the mother who is malnourished will increase the risk of the fetus conceived to be malnourished. If this happens continuously for a long period of time the child will fail in growth.

\section{The relationship between mother's knowledge about nutrition and health with stunting}

Fisher exact statistical test results obtained $\mathrm{p}$ value 1,000 showed that there was no significant relationship between maternal knowledge about nutrition with the incidence of stunting. The results of research conducted by Istiqomah, et al (2019) found no relationship between maternal nutrition knowledge and the incidence of 
stunting, based on a p-value of 1,000. In contrast to research conducted by Adelina, et al (2018) which states that there is a significant relationship between maternal nutrition knowledge with stunting based on the chi-squarepvalue 0.017 statistical test. OR value obtained 3.693 means that mothers who have less knowledge about nutrition are 3.693 times more likely to have a stunting child.

\section{Relationship between mother's age during pregnancy with stunting}

Chi-square statistical test results showed $\mathrm{p}$ value 0.151 meaning that there was no significant relationship between maternal age during pregnancy and the incidence of stunting. In line with research conducted by Nuraeni, et al (2019) in Tamansari Subdistrict, Tasikmalaya City, there was no relationship between maternal age at birth and stunting based on the chi-squaristic statistical test with a p-value of 0.234 . In contrast to research conducted by Sukmawati, et al (2018) which showed a relationship between maternal age during pregnancy and stunting based on a chi-square statistical test, a p-value of 0.01 was obtained.

\section{Relationship between mother's age during pregnancy with stunting}

Chi-square statistical test results showed $\mathrm{p}$ value 0.151 meaning that there was no significant relationship between maternal age during pregnancy and the incidence of stunting. In line with research conducted by Nuraeni, et al (2019) in Tamansari Subdistrict, Tasikmalaya City, there was no relationship between maternal age at birth and stunting based on the chi-squaristic statistical test with a p-value of 0.234 . In contrast to research conducted by Sukmawati, et al (2018) which showed a relationship between maternal age during pregnancy and stunting based on a chi-square statistical test, a p-value of 0.01 was obtained.

\section{The relationship between maternal nutritional status before pregnancy with stunting}

The results of the chi-square statistical test showed a $p$ value of 0.676 meaning that there was no significant relationship between the nutritional status of the mother before pregnancy and the incidence of stunting. This research contradicts the research conducted by Irawati and Salimar regarding maternal nutritional status factors before pregnancy with the length of the baby born in Gogor District showing a relationship between the nutritional status of pre-pregnant women and the length of the baby born. Pre-pregnant women who experience malnutrition will risk giving birth to a baby with LBW and if this continues in time it will further worsen the nutritional status of these children, especially at risk of future stunting.

Nutrition status, in this case the Stunting condition in children aged 36 - 59 months, can be influenced or caused by direct or indirect causative factors. The factors studied such as Birth Weight, Maternal Knowledge Level, Maternal Education Level, maternal age during pregnancy, nutritional status of the mother before becoming pregnant statistically had no significant relationship with stunting $(\mathrm{p}>0.05)$. Although this study found $6.9 \%$ of children with low birth weight, $2.5 \%$ of mothers with a lack of nutritional knowledge, $25 \%$ of mothers with low education levels, $45.1 \%$ of mothers who were less than 20 years old while pregnant, and $30.4 \%$ of mothers have abnormal nutritional status before becoming pregnant. Indirectly, these factors can influence stunting.

To achieve optimal height and weight, all nutrients (macro and micro) are needed in a balanced way, obtained from exclusive breastfeeding for up to 6 months, then continued with breast milk and complementary feeding.

\section{CONCLUSSION}

History of exclusive breastfeeding and complementary feeding are the risk factors for stunting.

\section{SUGGESTIONS}

Education for mothers and expectant mothers is needed in order to be able to change behaviors that can lead to the improvement of nutritional health, by encouraging continued breastfeeding until the age of 23 months accompanied by giving complementary feeding, and monitoring the growth and development of children by bringing to Posyandu every month.

Posyandu cadres under the guidance of health workers can provide counseling about balanced nutrition, clean and healthy living behavior, and the practice of breastfeeding and complementary feeding.

\section{ACKNOWLEGDE}

Thank you to the supporters of this activity, namely the Sam Ratulangi University Research and Community Service Institute (LPPM) as an institution that facilitates the implementation of this activity. This research activity was also supported by the Sitaro District Health Office and the Government and the community in the work areas of the Ulu Siau, Ondong, Talawid, Sawang, and Tagulandang Public Health Center. 


\section{REFERENCES}

Adelina, F.A.2018. Hubungan Pengetahuan Gizi Ibu dan Status Ketahanan Pangan Keluarga dengan Kejaadian Balita Stunting (Studi pada Balita Usia 24-59 Bulan di Wilayah Kerja Puskesmas Duren Kabupaten Semarang). Undergraduate thesis, Diponegoro University.

Buku Saku Pemantauan Status Gizi. 2017. Hasil Pmantauan Sttus Gizi. Kmentrian Kesehatan RI. Jakarta

Eggersdorfer, M., Klraemer, K., Ruel, M., Amerigen, M.V., Biesalski, K.H., Bloem, M., Chen, J., Lateef, A., and Mannar, V. 2013. The Road to Good Nutrition: A Global Perspective. Switzerland: Karger AG.

Hajar S, Tanjung I.S, Yurisna T, Zulfahmi. 2018. Pemberdayaan dan Partisipasi Masyarakat Pesisir. Lembaga Penelitian dan Penulisan Ilmiah Aqli. Medan.

Irawati, A., dan Salimar. 2014. Status Gizi Ibu Sebelum Hamil Sebagai Prediksi Berat Dan Panjang Bayi Lahir Di Kecamatan Bogor Tengah, Kota Bogor: Studi Kohor Prospektif Tumbuh Kembang Anak Tahun 2012 2013.The Journal Of Nutrition and Food Research. Vol 37, No. 2.

Istiqomah, A. 2019.Hubungan Antara Pengetahuan Gizi Ibu dan Tingkat Partisipasi Ibu Ke Posyandu Dengan Status Gizi Menurut TB/U Pada Anak Balita Di Desa Kemasan Kecamatan Sawit Kabupaten Boyolali. Universitas Muhammadiyah Surakarta.

Jiang, Y., Su, X., Wang, C., Zhang, L., Zhang, X., Wang, L., Cui, Y., 2015. Prevalence and risk factors for stunting and severe stunting among children under three years old in mid-western rural areas of China. Child. Care. Health Dev. 41, 45-51. https://doi.org/10.1111/cch.12148

Kementerian Kesehatan Republik Indonesia, 2016. Profil Kesehatan 2015. Jakarta: Kementerian Kesehatan Republik Indonesia. (www.depkes.go.id).

Kementerian Kesehatan Republik Indonesia (2014). Pedoman Gizi Seimbang. Jakarta : Bakti Husada

Kementerian Kesehatan Republik Indonesia (2013). Laporan Hasil Riset Kesehatan Dasar (RISKESDAS) Indonesia tahun 2013. Jakarta : Badan Penelitian dan Pengembangan Kesehatan.

Kementerian Kesehatan Republik Indonesia 2010. Laporan Survei Riset Kesehatan Dasar 2010. Jakarta: Kementrian Kesehatan RI

Kementerian Kesehatn R.I. 2018. Riset Kesehatan Dasar (RISKESDAS) 2018. Jakarta: Badan Penelitian dan Pengembangan Kesehatan

Keputusan Menteri Kesehatan RI. 2004 Pemberian Air Susu Ibu (ASI) Secara Eksklusif Pada Bayi Di Indonesia. Jakarta.

Kusumawati, M.R.D., Marina, R., Wuryaningsih, C.E., 2019. Low Birth Weight As the Predictors of Stunting in Children under Five Years in Teluknaga Sub District Province of Banten 2015, in: The 3rd IMOPH \& the 1st YSSOPH The 3rd International Meeting of Public Health and The 1st Young Scholar Symposium on Public Health. KnE Life Sciences, pp. 284-293. https://doi.org/10.18502/kls.v4i10.3731

Nuraeni, I., dan Diana, H. 2019. Karakteristik Ibu Hamil Dan Kaitannya Dengan Kejadian Stunting Pada Balita Di Kecamatan Tamansari Kota Tasikmalaya. Media Informasi.Vol. 15, No. 1.

Ni'mah, C., dan Muniroh, L. 2015. Hubungan Tingkat Pendidikan, Tingkat Pengetahuan dan Pola Asuh Ibu dengan Wasting dan Stunting Pada Balita Keluarga Miskin. Media Gizi Indonesia.Vol. 10, No. 1.

Rahmadi, A. 2017. Hubungan Berat Badan Dan Panjang Badan Lahir Dengan Kejadian Stunting Anak 12-59 Bulan Di Provinsi Lampung. Jurnal Ilmiah Keperawatan Sai Betik. Vol 12, No. 2.

Sari, A., Mambang, Putri, K.S.C.E., Haryono, I.A., Lestari, Y.P., Sari, M.Y., 2017. Advances in Health Science Research, volume 6 2nd Sari Mulia International Conference on Health and Sciences (SMICHS 2017), in: 2nd Sari Mulia International Conference on Health and Sciences (SMICHS 2017). Atlantis Press, Banjarmasin, pp. 1-11.

Sharlin J. dan Edelstein S. 2015.Buku Ajar Gizi Dalam Daur Kehidupan. Jakarta: EGC

SudargoT, Aristasari T, Afifah A.2018. 1000 Hari Pertama Kehidupan. Jogyakarta: Gadjah Mada University Press

Sukmawati, Hendrayati, Chaerunnima dan Nurhumaira. 2018. Status Gizi Ibu Saat Hamil, Berat Badan Lahir Bayi Dengan Stunting Pada Balita. Media Gizi Pangan.Volume 25 Nomor 1.

Susetyowati. 2017. Gizi Bayi dan Balita. Dalam: Ilmu Gizi Teori dan Aplikasi. Ed.Hardinsyah dan Supariasa. Jakarta: EGC

TNP2K.2017. 100 Kabupaten/kota Prioritas untuk Intervensi anak kerdil (stunting). Jakarta : Sekretariat Wapres.

Udoh, E.E., Amodu, O.K., 2016. Complementary feeding practices among mothers and nutritional status of infants in Akpabuyo Area, Cross River State Nigeria. Springerplus 5. https://doi.org/10.1186/s40064-0163751-7

Utomo B.S. 2018. Bersama Cegah Stunting. Warta Kesmas Ed.02. Jakarta : Kemenkes RI 